\title{
Disability Terms in Indonesian Translation of the Qur'an
}

\author{
${ }^{1 *}$ Mahalli \\ ${ }^{1}$ Center for Disability Studies and Services, Universitas Brawijaya, Malang, Indonesia; \\ Australia-Indonesia Disability Research and Advocacy Network (AIDRAN)
}

\begin{abstract}
This paper explores how terms of disability represented by Indonesian translation of the Qur'an. By selecting several words listed through the Mu'jamul Mufahras and other corpora, I explore the verses of the Qur'an, and then compare them with the Indonesia translation which has become the most authoritative source in Indonesia, produced by the Ministry of Religion of the Republic of Indonesia. I suggest, through the Social Model of Disability, some terms used in the translation should be contextually reviewed with appropriate terms.
\end{abstract}

Keywords: Disability, Translation, Qur'an, Terminology

\section{Research Background}

Around July 2019, a WhatsApp group consisting of several activists with disabilities discussed a possibility of proposing a revision of Indonesian Translation of the Qur'an undertaken by the Ministry of Religion of the Republic of Indonesia. The idea came after the Directorate General of Tashhih Al-Qur'an invited one of the group members to be involved in a focus group discussion on revising the translation. The Ministry of Religion responded it by initiating other FGD to specifically discuss about disability term which should be used in the next edition of Indonesian Translation of the Qur'an. Therefore, the people of the Center for Disability Study and Services Universitas Brawijaya compiled a policy brief reliably related to the revised translation.

I write this paper as a consideration for answering questions relating to the terms that would arise, especially those related to the terms of "disability". The key objective is to change dictions or words which have been used

* Corresponding author: Mahalli

mahalli.ra@gmail.com

Published online at http://IJDS.ub.ac.id/2014-

Copyright (C) 2019 PSLD UB Publishing. All Rights Reserved by the Ministry's version of the Qur'an. ${ }^{1}$ The translation by Ministry of Religion of the Republic of Indonesia becomes most recognized translation of the Qur'an by Islamic community in Indonesia. All of Al-Qur'an translations on the market, either published by the Indonesian government or private companies, have gone through a review process by the Ministry of Religion. In addition to the printed version, the Ministry of Religion also publishes Al-Qur'an and Its Indonesian Translation in digital versions, i.e. the website Qur'an Kemenag (https://quran.kemenag.go.id/) and Android-based application (Qur'an Ministry of Religion, https: // play.google.com/store/apps/details?id=com.qur an.kemenag\&hl=in).

The translation of the Qur'an into Indonesian and several local languages such as Javanese and Sundanese has a very long

${ }^{1}$ On Monday, October 16, 2019, when this paper was in review, the website of the Lajnah Pentashihan Mushaf Al-Qur'an, government-based institution in reviewing Indonesian translation of the Qur'an reported that Minister of Religion of the Republic of Indonesia Lukman Hakim Saifudin inaugurated the launch of the 2019 edition of the Improved Translation of the Qur'an in Hall of Bayt Al-Qur'an Building, Istiqlal Museum Taman Mini Indonesia Indah. The news stated that the latest edition of this translation was following Indonesian language standards, intelligible for young adults/younger generation, gender issues and persons with disabilities. 
history, with diverse versions, results, the influence of regime and political power, and criticism (Federspiel, 1994) (Ichwan, 2009). History of the Qur'an translation process was also overwhelmed with the context of epoch that prevailed when the translation took place, outside the debate whether translating the Qur'an is permitted by Islamic tenet or not. During that time, the translation progression brought the mindset of institutions, translators, and social context targeted by the Muslim or state intellectual authority that facilitated it (Tareen, 2017). Thus, in the form of translation or even interpretation, the Qur'an as a reference for Muslims is not utter precepts.

Indonesian translation of the Qur'an has had broad influence on Indonesian Muslims. It is not only in the form of religious understanding, but also how they have knowledge of certain discourses in everyday life (Ichwan, 2009), including terms which tend to be linked with "disability". These words have a meaning that in everyday understanding can be understood as disability, namely shummun (mute), bukmun (deaf), 'umyun (blind), akmah (blind since birth), dla'if (weak), safih (fool), abras (leper), and a'raj (stumbling) (Miles, 2002). In the form of Indonesian translation, the meaning of them are simplified without contextual description. For example, all summun are translated as tuli (deaf) without any further notes that they mean "spiritually deaf". The similarity in the choice of words of this translation has a tendency to be misconstrued and perpetuate uncooperative stigma to persons with disabilities.

\section{Qur'an and Disability: Literature Review}

Al-Qur'an is the first reference of Muslims. In addition to the Qur'an, within the framework of the Ahlu as-Sunnah wa al-Jamaah school in Indonesia, the second to fourth references are the hadith, consensus of ulama (ijma'), and analogy (qiyas) respectively. As the first and foremost inspiration, the Qur'an should be easily comprehended by Indonesian Muslims. This is the reason why its translation into Indonesian and several local languages in Indonesia is essential.

Considering the Qur'an as a revelation from God, some scholars have refused to translate it into languages other than Arabic.
For this reason, some Muslim groups in Indonesia lean to avoid the use of its translation, but attempt to grasp it through comprehensive interpretation, approached from the history of verse (asbab an-nuzul), how to understand it literally, to the collection of verses categorized thematically. Since this digital era, after quran.kemenag.go.id was published, an explanation of the interpretation of each verse followed. The option to display the interpretation or explanation can be retrieved directly in option buttons of each paragraph. Thus, Muslims in Indonesia who have an attentiveness in understanding the verses of the Qur'an can read the translation frankly as well as a more thorough explanation.

Although in the Qur'an some words associated with impairments such as summun, bukmun, and 'umyun, the concept of disability in a conventional sense is not found (Bazna \& Hatab, 2008). These words are not correlated with disability as the understanding conveyed by the inclusion movement towards persons with disabilities. Nevertheless, according to Bazna and Hatab (Bazna \& Hatab, 2008), the Qur'an contains wisdoms about responsibility to disadvantaged individuals, both socially, economically, and physical attributes:

\footnotetext{
"... Rather, the Qur'an concentrates on the notion of disadvantage that is created by society and imposed on those individuals who might not possess the social, economic, or physical attributes that people happen to value at a certain time and place. The Qur'an places the responsibility of rectifying this inequity on the shoulder of society by its constant exhortation to Muslims to recognize the plight of the disadvantaged and to improve their condition and status."
}

Based on the history of movements that demand equality and equity of the rights of persons with disabilities, this view is relatively similar to the view of the charity model. Charity model in disability issues places a person with disabilities as an object. On the one hand, it is identical with medical models in different areas. Both are against the social model of disability which positioned people with disabilities as subjects of empowerment.

Differently on charity, medical, and social model of disability bring indispensable sense in the use of terms. "The disability terminology debate is about seeing people as 
persons first, rather than focusing on their medical conditions" (Shakespeare, 2018). The impact of using these terms reflects how we think and have viewpoints about inclusion for people with disabilities.

These terms historically change as views cultivate. In the 1980s, the World Health Organization (WHO) defined disability as a personal attribute, "In the context of health experience, a disability is any restriction or lack of ability (resulting from an impairment) to perform an activity in the manner or within the range considered normal for a human being" (WHO, 1980). In its current development, WHO calls it context-dependent, "Disability is not just a health problem. It is a complex phenomenon, reflecting the interaction between features of a person's body and features of the society in which he or she lives" (WHO, 2017). The label transformation has slightly changed the community's behavior of disability conditions (King, 2019).

In the social model of disability, the use of the term accentuates the subjectivity of individuals with disabilities. Tom Shakespeare provides an illustration of the use of appropriate and commonly used terms today, namely "people with disabilities", "people with chronic illness", "people with learning difficulties", "persons with cerebral palsy", "Deaf" or "hard of hearing persons", "people with mental health conditions", "service user", "persons with schizophrenia" (Shakespeare, 2018). In the Indonesian context, the use of these terms is exemplified in Law Number 8 of 2016 concerning Persons with Disabilities. The terms used in the act are "persons with physical disabilities", "persons with intellectual disabilities", "persons with mental disabilities", and "persons with sensory disabilities".

In everyday life, what has been known as deaf is preferably termed Deaf, with large D. Deaf people acknowledge themselves as sign language users rather than individuals who have imperfect communication ability. In the law, a Deaf person is categorized as a person with sensory disabilities along with blind and person with speech difficulties. The terms chosen in the law differ from what is known in the culture of persons with disabilities' organization or movement because it is a legal result that has purpose of policy formulation and technical implementation, both in the form of services and empowerment.

This paper will use more specific terms with consideration to bridge them in the law and the terms recognized by movements or disability organizations. The terms are including "persons with disabilities", "Deaf", "persons with visual impairments", "persons with speech disabilities", "persons with mental disabilities", "persons with intellectual disabilities", and "people affected by leprosy". Word "leper" is also included here based on WHO explanation (WHO, 2017) that leprosy is one of the causes of permanent disability.

\section{Exploring the Verses}

Al-Qur'an and Its Indonesian Translation is a translation of the Mushaf Utsmani commonly used in Southeast Asian. The composition consisted of 30 chapters and 114 surahs, began with Al-Fatihah and completed with An-Nas. History of translation of the Qur'an in Indonesia through a protracted history covering the colonial era to contemporary day. During that time, the translation of the Qur'an was crammed with numerous versions, translated by individuals, rulers in the colonial era, until accommodated by the government under the Ministry of Religion (Ichwan, 2009) (Federspiel, 1994). From the Qur'an and Its Indonesian Translation in the Utsmani version, I find seven words related to disability terms in 36 different surahs.

As mentioned above, the terminologies are bukmun (mute), summun (deaf), umyun (blind), akmah (blind since birth), a'raj (stumbling), safih (fool), and dla'fun (weak). These terms have different interpretations. By categorizing various kinds of disabilities, I look for the words in the Al-Qur'an translations and corpora such as Mu'jamul Mufahras and corpus.quran.com. I also refer to the other papers on the Qur'an and disability, such as the writings of Maysaa S. Bazna \& Tarek A. Hatab (2005), M. Mills (2002), Mohammed Ghaly (2019) and Staffan Bengtsson (2018).

In the following step, I scrutinize the explanations of each verse in Tafsir Jalalain, Tafsir Shawi, Tafsir Al-Mishbah, and The Study of the Qur'an: A New Translation and Commentary. It provides critical interpretations, such as whether the verse contains "disability" 
in the physical framework or spiritual insensibility. With this step, I would like to give a suggestion in line with the point of view of the social model of disability. It places the terms so that they are not in an equal position as the verse which contains teaching about spiritual insensibility.

\section{Disability Term in Indonesian Translated Verses}

In the Al-Qur'an and Its Indonesian Translation, quran.kemenag.go.id and the printed version circulating widely in Indonesian Muslim nowadays, the meaning of all the words is relatively identical without distinguishing between verses which contain physical attribute and spiritual insensibility. Those words need to be reconsidered as the translation becomes more appropriate and in line with the spirit of inclusion for persons with disabilities.

In the following paragraphs, I will portray in detail the words above based on their triliteral root. This method is to make them easy to be found in their surahs.

\section{Sād Mīm Mīm}

The triliteral root șâd mìm mìm (ص م م) occurred 15 times in the Quran in three derived forms. It is twice as the form I verb sammu

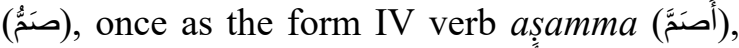
12 times as the noun aṣamm (أَصَّمَ) in fourteen different verses (Nasr, Lumbard, Dagli, Dakake, \& Rustom, 2017).

In the detailed explanation, all triliteral root șād mim mìm (ص م م) mean "deaf" from the call to religious truth and belief, heart deafness, or deafness proposed as an analogy to polytheism (Al-Mahalli \& Jalaluddin AsSuyuthi, 2001) (Shihab, 2005a). In Indonesian Translation of the Qur'an, this word is converted as tuli (deaf), without obvious account that the deaf implied to is not physically deaf.

\section{$B \bar{a} \boldsymbol{K a} \tilde{f}$ Mìm}

The triliteral root $b \bar{a} k \bar{a} f \operatorname{mim}$ (ب) occurred six times in the Quran in three derived forms as the noun abkam (بَأَبَّم), bukmu (بكم), and bukmā (بكما) in six difference verses (11). It also means spiritually mute, with several meanings such as "not caring about religious truth" and "not thinking" (Al-Mahalli \& Jalaluddin AsSuyuthi, 2001) (Shihab, 2005a) (Shihab, 2005c).
In the Qur'an and Its Indonesian Translation, all triliteral root $b \bar{a} k \bar{a} f \operatorname{mim}(ب)$ (ب ك م) is translated as bisu (mute). One of the six words is explained in parentheses, namely in Surat Al-Anfal (8): 22 about God's view of people who do not want to understand the appeal to the truth.

\section{'Ayn Mìm Yā}

The triliteral root 'ayn mìm yāa (ع) occurred 33 times in the Quran in five derived forms. It is seven times as the form I verb 'amiya (عَمِى), once as the form II verb 'ummiyat (عُمِيَّنَ), twenty one times as the nominal $a^{\prime} m \bar{a}$

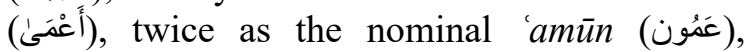
twice as the noun ama (عَىَ) in thirty difference verses (al-Baqi, 1364H).

The translation of this word depends on the context of use in each verse. They and their derived forms are translated as buta (blind). 30 of the 33 verses are associated with "spiritual blindness or darkness". The remaining three are "physically blind". Interestingly, as stated by Bazna and Hatab (Bazna \& Hatab, 2008), the word ('amiya) did not carry a negative connotation for the seventh century Arabs. It's merely referred to the specific conditions of not seeing."

In its Indonesian translation, 30 triliteral root of 'ayn mìm yā did not mean "physically blind". Three of them had been acceptable linguistically, three translated suitably, and six explained with further descriptions in parentheses. The three verses which have been translated correctly are Hud (11): 28, AlQashash (28): 66, Fushilat (41): 44. The three other words are translated as "darkness" and "disguise". For the three 'ayn mìm $y \bar{a}$, in Indonesian translation of the Qur'an they should be replaced by "penyandang disabilitas netra" as a more appropriate term.

\section{Käf Mīm Hā}

The fourth is akin to the previous word, namely triliteral root kaf mim hā ( 0 ( ) which means "blind since birth". It occurred twice in the Quran as the noun akmah (أَكَمَّ) in two difference verses. Those are related to the story of the miracles given by God to Jesus, who was able to cure people with leprosy, make blindsince-birth people see and raised the dead from grave. The words are in Ali 'Imran (2): 49 and Al-Maidah (5): 110 (al-Baqi, 1364H). The word akmaha, both literally and contextually, means 
physically blind since birth (Al-Mahalli \& Jalaluddin As-Suyuthi, 2001) (Shihab, 2005b).

In its translation, this word is translated as buta (blind). In the Indonesian context, and also related to the context of the verse, the word in these two verses need to be changed to "persons with visual disabilities since birth". An added use of the explanation "from birth" is to distinguish it from "amiya which could mean physically blind not since birth.

\section{'Ayn Rā Jīm}

The triliteral root 'ayn rā jim (ج $(\varepsilon)$ occurred nine times in the Qur'an in three derived forms. It is five times as the form I verb

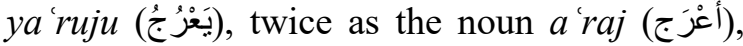
twice as the noun ma ārij (مَعَارِج) in two difference verses, An-Nur (24): 61 and Al-Fath (48): 17 (al-Baqi, 1364H). Among nine of its derived forms, only the word $a^{\prime} r a j$ is associated with disability term, which means "lame". The other seven words mean "ascend".

The word $a^{\prime} r a j$ in the Qur'an and Its Indonesia Translation is translated as "lame people". Because this word is not proposed as a metaphor, the translation needs to be improved to "people with physical disabilities". In Surat An-Nur (24): 61, it even contains appeals relating to social inclusion in the family circle (Al-Mahalli \& Jalaluddin As-Suyuthi, 2001).

\section{Däd 'Ayn Fā}

The triliteral root dẹad 'ayn fā (ض ع ف) occurred 52 times in the Quran in 11 derived forms. It is twice as the form I verb da $u f a$

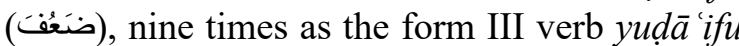

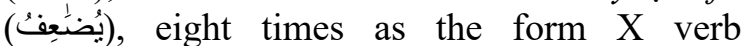

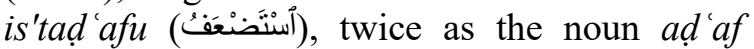
(يَضْعِفَ

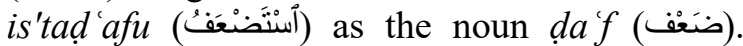
Eleven times as the nominal $d i i^{\prime \prime} f$ (ضِنَ), four times as the noun $d a$ ' $f(ض َ ع َ)$, eight times as the nominal da if (ضَعِيف), once as the adjective

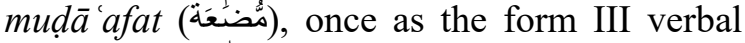
noun di 'a f (ضِعَف), once as the form IV active participle muḍd'ifün (مُضْعِفُون), five times as the form $\mathrm{X}$ passive participle mus'taḍ'afün (مُسنَضْضْفَفُون). These words are in forty-five different verses (al-Baqi, 1364H).

The word rooted from the triliteral $d \bar{a} d$ 'ayn $f \bar{a}$ (ض) in the Qur'an has three different kinds of meaning, namely "weak" (including disadvantaged and oppressed) and "multiplication". These two different notions must be carefully categorized. In the 11 forms

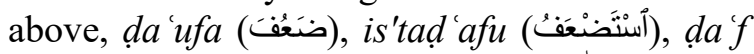

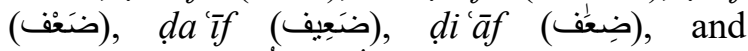

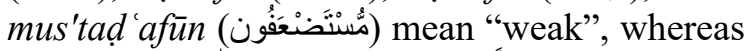

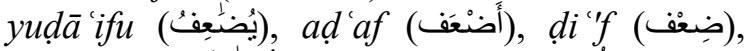

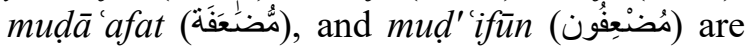
"multiplication".

Triliteral roots of ḍâd 'ayn fāa (ض ع ع (ض) which mean "weak" and "oppressed" generally do not refer to the concept of being physically weak. Among the 18 words containing this triliteral root which mean weak, 15 words mean "physically weak", not spiritually. The words are in Al-Baqarah 266 and 282, An-Nisa '9, 75, 97, 98, and 172, Al-A'raf 137 and 150, AlAnfal 26, At-Taubah 91, Hud 91, Al-Qashash 4 and 5, and Ar-Rum 54. The triliteral root $d \bar{a} d$ 'ayn fāa (ض ع ع in the verses means variably, varying in physical weakness and debilitating environmental conditions. Interestingly, AlBaqarah 282 is related to prohibition to people with reason weakness to be involved in debt transactions. Another, At-Taubah 91 explains that people with physical weakness are not in obligation to join war (Shihab, Tafsir AlMishbah: Pesan, Kesan, dan Keserasian AlQur'an, 2005a). In Indonesian translation of the Qur'an, these words were translated as lemah (weak). It does not have negative connotations in Indonesian language or disability terms. However, people's understanding of being physically weak may automatically insinuate people with disabilities.

\section{$B \bar{a} \operatorname{Ra} S \bar{a} d$}

The triliteral root $b \bar{a}$ rā șād (ب, ص) occured twice in the Quran in two different verses as the noun abraṣ (أَبْرَص (al-Baqi, $1364 \mathrm{H}$ ). As well as akmaha, the word abras is in the same two verses which tell the miracles given by God to Jesus. The two verses are related to the concept of physical illness, not spiritual (Long, 2011). In the Qur'an and Its Indonesian Translations, the words are translated as "lepers". In Indonesia, there is no word to refer to "leper" as in English. Thus, the use of the translation of "people affected by leprosy" or "people with leprosy" has prioritized the existence of individual subjects as commonly used to refer to persons with disabilities in the framework of social models of disability. 


\section{Sìn Fā Hā}

The triliteral root $\sin f \bar{a} h \bar{a}(0$ w) occurred 11 times in the Quran in four derived forms. It is once as the form I verb safiha (سَفِفَ),

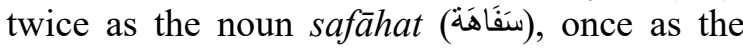
noun safah (سنَف), seven times as the noun safih (سَفِيَ) in ten different verses (al-Baqi, 1364H). The words in the Qur'an and Its Indonesian Translations are translated variously. Only one verse, in my observation, needs to be changed in its translation, namely in Surat Al-Baqarah (2): 282 which should be translated in more appropriate terms. Currently it is still translated as orang yang kurang akal (the one who lacks reason).

In the form of translation, it needs to be replaced by other appropriate words. M. Quraish Shihab explains that it can be in the form of an inability to manage ownership (Shihab, 2005a). According to Al-Mahalli and As-Syathibi (2001), it is precisely the behavior of wasting (mubaddzir) ownership. Since the verse is on the ability and maturity to manage ownership (mukallaf), it is necessary to discover other terms apposite to disability issues.

\section{From Translation to Discourse Shift}

As discussed above, the terms related to disability in the Al-Qur'an and Its Indonesian Translation still contain bias. Some verses are still translated with Indonesian words less appropriate in accordance with the spirit of the inclusion. In the recent discourse of disability issues in Indonesia, the adaptation of perspective from human rights approach invents some Indonesian terms in line with inclusion, for instance "penyandang disabilitas" as the Indonesian version of "people with disabilities" to replace the old term "penyandang cacat". Social construction of disability, through alteration in terminology usage, has transformed the discourse of inclusion (Oliver, 1990). It apparently conveys positive messages which change the way people treat persons with disabilities. The terms deployed in the translation follows old definitions that require a renewal version to shift discourse.

Although there are only a few verses honestly related to persons with disabilities, the Qur'an encompasses positive message about the value of inclusion. In Indonesia, the translation of the Qur'an by following the spirit of contemporary view about social inclusion for people with disabilities will affect alterations of stereotypes to be more positive. As the first and foremost source, it positively influences the use of terms in other references such as hadith, ijma', and qiyas. If terminology is a perceptible representation of ways of thinking, transformations will gradually affect the overall pattern structurally reflected in our social life.

\section{Bibliography}

al-Baqi, M. F. (1364H). Al-Mu'jam al-Mufahras li Alfazh al-Qur'an al-Karim. Kairo: Darul Kutub Al-Mishriyyah.

Al-Mahalli, J., \& Jalaluddin As-Suyuthi. (2001). Tafsir Jalalain. Kairo: Darul Hadits.

Bazna, M., \& Hatab, T. (2008). Disability in the Qur'an: The Islamic Alternative to Defining, Viewing, and Relating to Disability. Journal of Religion, Disability \& Health, 9(1), 5-27.

Federspiel, H. M. (1994). Popular Indonesian Literature of the Qur'an (Cornell Modern Indonesia Project ed.). Itacha: Cornell University.

Ichwan, M. N. (2009). Negara, Kitab Suci dan Politik: terjemah Resmi Alquran di Indonesia. Dalam H. Chambert-Loir (Penyunt.), Sadur: sejarah Terjemahan di Indonesia dan Malaysia (hal. 417433). Jakarta: Kepustakaan Populer Gramedia.

King, D. (2019, October 20). The Way We Talk About Disabilities Is Evolving. Is It Evolving Fast Enough? Diambil kembali dari Mother Jones: https://www.motherjones.com/media/2 019/10/disability-language/

Long, M. L. (2011). Leprosy in Early Islam. Dalam D. Schumm, \& M. Stoltzfus (Penyunt.), Disability in Judaism, Christianity, and Islam: Sacred Texts, Historical Traditions, and Social 
Analysis (hal. 43-62). New York:

Palgrave Macmillan.

Miles, M. (2002). Some Historical Texts on Disability in the Classical Muslim World. Journal of Religion, Disablility \& Health, 6(2-3), 77-88.

Nasr, H., Lumbard, J., Dagli, C., Dakake, M. M., \& Rustom, M. (2017). The Study Qur'an: A New Translation and Commentary. London: HarperOne.

Oliver, M. (1990). The Politics of Disablement. New York: Palgrave Macmillan

Shakespeare, T. (2018). Disability: The Basic. New York: Routledge.

Shihab, M. Q. (2005a). Tafsir Al-Mishbah: Pesan, Kesan, dan Keserasian AlQur'an (Vol. 1 Surat Al-Fātihah dan Al-Baqarah). Jakarta: Lentera Hati.

Shihab, M. Q. (2005b). Tafsir Al-Mishbah: Pesan, Kesan, dan Keserasian AlQur'an (Vol. 2 Surah Āli 'Imrān dan Surah An-Nisā'). Jakarta: Lentera Hati.

Shihab, M. Q. (2005c). Tafsir Al-Mishbah: Pesan, Kesan, dan Keserasian AlQur'an (Vol. 3 Surah Al-Mā'idah). Jakarta: Lentera Hati.

Tareen, S. (2017). Revolutionary hermeneutics: translating the Qur'an as a manifesto for revolution. Journal of Religious and Political Practice, 3(1-2), 1-24.

WHO. (1980). International Classification of Impairments, Disabilities, and Handicaps. Geneva: World Health Organization.

WHO. (2017). Disabilities. Dipetik September 16, 2019, dari WHO: https://www.who.int/topics/disabilities/ en/

WHO. (2017). World Health Organization Regional Office South East-Asia.
Dipetik August 3, 2019, dari Global Leprosy Program: http://www.searo.who.int/entity/global_ leprosy_programme/leprosy_as_a_dise ase/en/ 